\title{
Macrophytes communities associated to soil bioengineering techniques for erosion control in riverbanks ${ }^{1}$
}

\author{
Maria Hosana Santos ${ }^{2}$ (D), Francisco Sandro Rodrigues Holanda ${ }^{2 *}$ (D), Janisson Bispo Lino ${ }^{2}$ (D), \\ Tássio Lucas Souza Santos ${ }^{2}$ (D), Cátia Santos Fontes ${ }^{2}$ (1), Marks Melo Moura ${ }^{3}$ (D), \\ Renisson Neponuceno Araújo Filho 4
}

\author{
'Parte da dissertação do primeiro autor, Programa de Pós-graduação em Agricultura e Biodiversidade, \\ Universidade Federal de Sergipe, Brasil. \\ 2Universidade Federal de Sergipe, Departamento de Engenharia Agronômica, campus São Cristovão. \\ Av. Marechal Rondon, s/n, CEP 49100-000, São Cristóvão, SE, Brasil. \\ *Autor para correspondência: fholanda@infonet.com.br \\ ${ }^{3}$ Universidade Federal do Paraná, Departamento Ciências Florestais, Av. prof. Lothario Meissner, 900, CEP 80210-170, Curitiba, PR, Brasil. \\ ${ }^{4}$ Universidade Federal do Tocantins, Curso de Engenharia Florestal, campus Gurupi. Rua Badejos, s/n, CEP 77404-970, Gurupi, TO, Brasil.
}

ABSTRACT - The objective of this study was to evaluate the temporal and spatial richness of aquatic macrophyte settlement in a right bank of the São Francisco river, northeastern Brazil. The botanical material was collected and assembled exsiccate from April 2014 to September 2015 , totaling four samplings at the points identified as: Vegetated Slope (A); Vegetated Riprap (B); Eroded Slope (C), Cribwall (D); Vetiver Grass Contour Line (E). It was identified 66 species distributed in 23 families. The Vegetated Slope in the rainfall period presented higher species richness and diversity. The soil bioengineering techniques at points $\mathrm{B}, \mathrm{D}$ and $\mathrm{E}$ presented a stable river bank, thus creating a favorable environment for a larger settlement of macrophytes.

Keywords: biodiversity, cribwall, Lower São Francisco, riprap

RESUMO - Comunidades de macrófitas associadas a técnicas de bioengenharia do solo para controle de erosão em margens de rios. O objetivo do trabalho foi avaliar a riqueza temporal e espacial do povoamento de macrófitas aquáticas em um talude da margem direita do rio São Francisco, no nordeste brasileiro. O material botânico foi coletado para montagem de exsicata, no período de abril de 2014 a setembro de 2015 , totalizando quatro amostragens, nos pontos identificados como: (A) Talude Vegetado, (B) Enrocamento Vegetado, (C) Talude Erodido, (D) Parede Krainer e (E) Cordão de Vetiver. Foram identificadas 66 espécies distribuídas em 23 famílias. Talude Vegetado no período de chuvas apresentou maior riqueza e diversidade de espécies. As técnicas de bioengenharia de solos nos pontos B, D e E possibilitaram a estabilização dos taludes na margem do rio, e assim, criando um ambiente favorável para um maior povoamento de macrófitas.

Palavras-Chave: Baixo São Francisco, biodiversidade, enrocamento, Parede Krainer

\section{INTRODUCTION}

Macrophytes compose a taxonomic diversity of organisms with different life forms, which extend from floodplain areas to fully aquatic environments, populated by organisms from algae to angiosperms (García-Girón et al. 2019). Macrophytes are classified as emerged, rooted plants, and their leaves remain out of the water; floating plants, free floating, rooted to the sediment, and their leaves remain floating on the water surface; submerged plants, rooted to the sediment, totally submerged; free submerged plants, which develop floating submerged in the water (Moura \& Henry-Silva 2018).

Given the diversity and the distribution in the ecosystem, macrophytes play an important ecological role in lentic environments, providing an attractive environment for fauna development (from vertebrates to several invertebrates), either as shelter, or as feed (Dhir 2015). Besides its important role contributing to nutrient cycling, some macrophytes, especially the free-floating, rooted submersed and emerged, are effective in pollutant removal (Shah et al. 2015).

The colonization of aquatic macrophytes is associated with the availability of dissolved nutrients, light, temperature, alkalinity, salinity, river discharge and speed, which together act on these communities (Chen \& Wang 2019). In fact, the control of the hydrological regime results in changes in biological fresh water communities and in the physicochemical conditions of the water (Howard et al. 2016), creating different environments, allowing the occurrence of greater species diversity. 
Hydrological changes frequently occur in large rivers worldwide, reflecting on shifts along the channel by means of water impoundment, either for the use in electric power generation, or for human consumption, irrigation, flood control, navigation, and leisure. In the São Francisco River, the past fifty years were marked by the establishment of hydroelectric plants throughout its channel, which significantly altered the hydrosedimentological dynamics of this ecosystem (Rocha et al. 2018), leading to increased occurrence of erosion in its banks, which demands the implementation of mitigation works regarding these environmental threats (Andrade et al. 2018).

Another consequence is the instability of the soil aggregates after vegetation removal, which contributes to erosive processes (Machado et al. 2018; Oliveira et al. 2009). In order to mitigate the damage caused by erosion, scientists have developed engineering techniques combined with ecological knowledge on plant species that contribute to the roots mechanical reinforcement for erosion control (Holanda et al., 2007; Holanda et al., 2009; Araújo-Filho et al. 2017).

Costa et al. (2020) stated the importance of vegetation in the riverbanks erosion control, and also Machado et al. (2018) showed in their work the importance of knowing the species morphological characteristics, in order to enable positive performance in slope stabilization. This shows that soil bioengineering techniques favor erosion control and increased biodiversity related to aquatic plant species. The objective of this work was to evaluate the temporal and spatial richness of the macrophytes communities on the slopes of the São Francisco River margins associated to use of soil bioengineering techniques.

\section{MATERIAL AND METHODS}

\section{Collection Area}

The study was carried out on the right margin of the São Francisco River, in the municipality of Amparo de São Francisco coordinates W 36 $50^{\circ} 25.335^{\prime \prime}$ and S $10^{\circ} 13^{\prime} 34.081$ ', in Sergipe state, Northeastern Brazil. The climate was characterized As type (tropical, with two well defined seasons, dry summer and rainy winter), according to the Peel et al. (2007) classification, with average annual rainfall of $744 \mathrm{~mm}$ year ${ }^{-1}$ and temperature of $25^{\circ} \mathrm{C}$ (INMET 2015).

The floristic survey on the slope was carried out monthly from April 2015 to September 2015, along the riverbank. Ten plots $30 \times 30 \mathrm{~cm}$ were randomly installed and macrophytes with the presence of a flower were removed in each plot. All flowery individuals found on the slope and in places immediately associated with the slopes, that is, close to the river channel, were taken for later identification.

The collection sites were chosen considering the development of macrophytes communities at the slope toe in the São Francisco River, after the implementation of some soil bioengineering techniques as a result of a favorable hydrosedimentological environment. The Vegetated Riprap, the Cribwall, and Vetiver grass (Chrysopogon zizanioides (L.) Roberty) contour lines were considered among the techniques used in the experimental area. These techniques promote erosion control, stabilize the slopes, and provide environment for flora development and shelter for the aquatic fauna (Araujo-Filho et al. 2013).

\section{Sample collection}

The collections of botanical material were carried out in plots along the $200 \mathrm{~m}$ extension of the river bank. The collection sites were: Vegetated Slope (A); Vegetated Riprap (B); Eroded Slope (C), Cribwall (D); Vetiver grass Contour Line (E) (Fig. 1).

Among the collection sites, three of them (B, D and E) are composed by soil bioengineering techniques (AraujoFilho et al. 2013). Site "A", identified as Vegetated slope, is characterized as an area covered by native vegetation, with strong presence of aquatic macrophytes; Site "B", the Vegetated Riprap, comprises one of the soil bioengineering techniques, implanted at the slope toe in 2011 composed by rock materials with different diameters, and was vegetated with species of local flora, and also populated with other species resulting from seed dispersal by fauna and the wind; Site "C", the Eroded Slope, had different number of plant individuals at its toe, depending on the rainfall and river discharge during the collection period; Site " $D$ ", the Cribwall, is another soil bioengineering technique, which consists of the stabilization of the river slope with wooden logs, clamps and living material, implanted in September 2013, and was also vegetated with a great number of macrophytes at its toe; Site "E", the Vetiver grass Contour Line, consisted of seedlings of vetiver grass planted in contour lines, following the concavity of the river margin. Plant collection was carried out using a canoe at low speed, with concomitant photographic and iconographic records.

The preparation of the collected plant material followed conventional methods, such as drying and exsiccate methods (Rodrigues et al. 2017). After that, the material was taken to the Herbarium - ASE of the Universidade Federal de Sergipe, for identification. The taxonomic identification was carried out by comparing the collected material. In addition, specialized studies and experts references were used (Pott \& Pott 2000; Lorenzi 2008; Souza \& Lorenzi 2008).

\section{Analyzes}

In order to evaluate the biodiversity richness data of the study sites, we used the richness estimation method from the sample data (Cullen et al. 2006). Also using the accumulation curve, the richness of the aquatic macrophytes species was verified at the sampling sites, and was estimated by non-parametric indexes. These indexes were based on the presence or absence of the species (Chazdon et al. 1998), using the Estimates software (Colwell 1997). Among the estimators, Chao2, Jacknife (Jack1), and Bootstrap were selected once they have been used in studies with macrophytes, based on a similar collection methodology (Bini et al. 2001). 

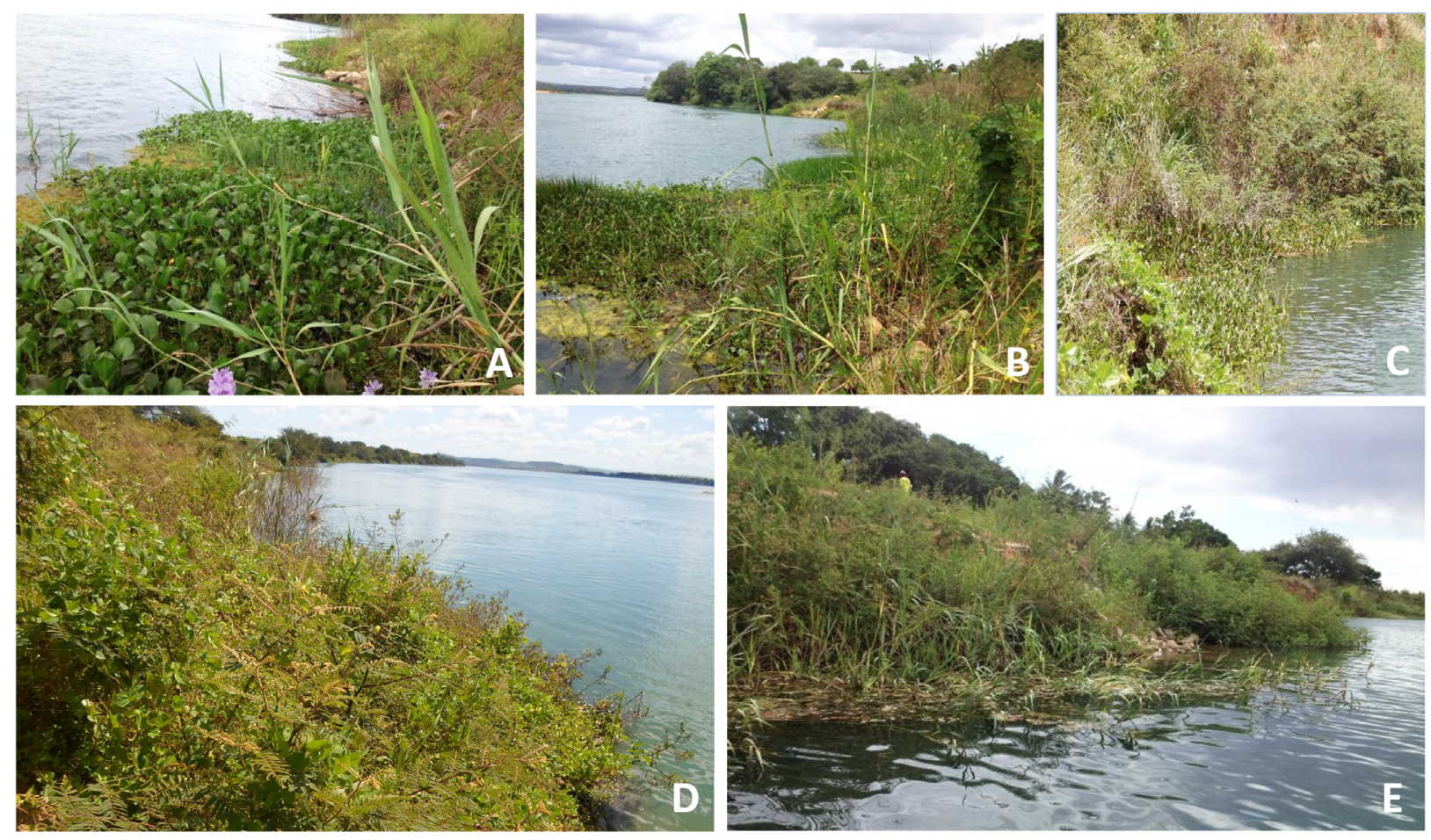

Figs. 1. A-E. Collection sites of aquatic microphytes at Amparo de São Francisco. A. Vegetated Slope; B. Vegetated Riprap; C. Eroded Slope; D. Cribwall; E. Vetiver Grass Contour Line.

The Jaccard Index was applied using the PasT software to estimate a similarity matrix between the sampling periods and the sampling sites, as an indicator of the degree of temporal stability in relation to the community composition. To compare the macrophytes communities identified among the collection sites, a temporal patterns at the sampling periods was performed, allowing the comparison by the Tukey test $(\mathrm{p}<5 \%)$, using the statistical software SISVAR (Ferreira 2011).

\section{RESULTS AND DISCUSSION}

Sixty six aquatic macrophytes species were recorded, distributed in 23 families (Tab. 1), showing the richness of species of the São Francisco River banks.

Other studies in different water systems report the occurrence of macrophytes as long as there are conditions for the development of such species (Araújo et al. 2012), who evaluated the richness and diversity of aquatic macrophytes in Caatinga biome springs, and found 52 species distributed in 25 families.

When we studied species lifeforms, $83 \%$ species were found amphibious, i.e., they are adapted to variations in water level, considering that the riverbanks were identified as the interface between the aquatic and terrestrial environment, enabling a wide variety of species (Sponchiado \& Schwarzbold 2009). We also identified submerged species $(5 \%)$, emerged species $(5 \%)$, rooted submerged species $(1 \%)$, and free floating species $(6 \%)$.
These are differentiated distribution patterns, in agreement with the studies by Bianchini Junior et al. (2010) and Mormul et al. (2010).

The presence of the species Salvinia auriculata Aubl. var. auriculata, Pistia stratiotes var. obcordata (Schleid.) Engl. and Eichhornia crassipes (Mart.) Solms in every collection shows their invasive character. Despite the hydrological changes, with the decrease of the river discharge and lowering of the water level, these species maintained their population with an remarkable occurrence. Moura-Junior (2012), conducting the studies in the Cursai and Tapacurá reservoirs, state of Pernambuco, also identified the maintenance of these species in two distinct periods of hydrological changes. These species have morphophysiological plasticity, which allows them to occupy continental ecosystems and brackish water (Moura Júnior \& Cotarelli 2019).

Significant difference $(\mathrm{p}<0.05)$ was observed for richness between sampling sites. The Vegetated slope site presented 69 species, while the Vetiver grass Contour Line presented 30 (Fig. 2).

This reflects the less favorable conditions for the species development in the Vetiver grass Contour Line, since it presents a sandy soil with less favorable edaphic, ecological and geomorphological conditions for macrophytes, because they are in the concave stretches of the riverbank, where erosion is more active, noticed by higher erosive rates.

The species accumulation curve (Fig. 3) shows the observed richness in contrast with the estimated richness. 
Table 1. Aquatic macrophyte species in the study area at Amparo de São Francisco. Biological forms: Amphibious (AM), Free (FR), Rooted Submerged (SUB ROT), Free floating (FFLU) and Emerged (EM)

\begin{tabular}{|c|c|c|c|c|}
\hline Family & Specie & Life Form & Richness & Voucher \\
\hline Amaranthaceae & Alternanthera tenella Colla & $\mathrm{AM}$ & 1 & ASE 33516 \\
\hline Araceae & Pistia stratiotes $\mathrm{L}$. & FFLU & 4 & ASE 33604 \\
\hline \multirow[t]{13}{*}{ Asteraceae } & Emilia fosbergii Nicolson. & $\mathrm{AM}$ & 3 & ASE 33579 \\
\hline & Blainvillea dichotoma (Murray) Stewart & $\mathrm{AM}$ & 1 & ASE 33585 \\
\hline & Tilesia baccata (L.f.) Pruski & $\mathrm{AM}$ & 1 & ASE33558 \\
\hline & Emilia sonchifolia $(\mathrm{L})$ DC. ExWight & $\mathrm{AM}$ & 3 & ASE 33542 \\
\hline & Eclipta prostrata $(\mathrm{L}) \mathrm{L}$. & $\mathrm{AM}$ & 2 & ASE 33530 \\
\hline & Porophyllum ruderale (Jacq.) Cass & $\mathrm{AM}$ & 5 & ASE 33510 \\
\hline & Mikania cordifolia (L.f.) Willd & $\mathrm{AM}$ & 6 & ASE 33501 \\
\hline & Conyza cf. bonariensis (L.) Cronquist & $\mathrm{AM}$ & 1 & ASE 33508 \\
\hline & Ageratum conyzoides $\mathrm{L}$. & $\mathrm{AM}$ & 7 & ASE 33520 \\
\hline & Tridax procumbens $\mathrm{L}$. & $\mathrm{AM}$ & 1 & ASE 33548 \\
\hline & Pluchea sagittalis (Lam.) Cabrera & $\mathrm{AM}$ & 2 & ASE 33523 \\
\hline & Melanthera latifolia(Gardner) Cabrera & $\mathrm{AM}$ & 3 & ASE 33557 \\
\hline & Synedrella nodiflora (L.) Gaertn & $\mathrm{AM}$ & 1 & ASE 33545 \\
\hline \multirow[t]{2}{*}{ Convolvulaceae } & Jacquemontia sp. & $\mathrm{AM}$ & 2 & ASE 33575 \\
\hline & Ipomoea asarifolia (Desr.) Roem. \& Schult. & $\mathrm{AM}$ & 3 & ASE 33506 \\
\hline Cucurbitaceae & Momordica charantia $\mathrm{L}$ & EM & 3 & ASE 33546 \\
\hline \multirow[t]{4}{*}{ Cyperaceae } & Cyperus surinamensis Rottb. & $\mathrm{AM}$ & 5 & ASE 33513 \\
\hline & Cyperus blepharoleptos Steud. & EM & 2 & ASE 33568 \\
\hline & Cyperus compressus $\mathrm{L}$. & $\mathrm{AM}$ & 2 & ASE 33569 \\
\hline & Cyperus odoratus L. & $\mathrm{AM}$ & 10 & ASE 33559 \\
\hline Euphorbiaceae & Euphorbia hyssopifolia (L.) & $\mathrm{AM}$ & 2 & ASE 33550 \\
\hline \multirow[t]{12}{*}{ Fabaceae } & Centrosema pascuorum Mart. ex Benth. & $\mathrm{AM}$ & 2 & ASE 33529 \\
\hline & Aschynomene sensitive $\mathrm{Sw}$. & $\mathrm{AM}$ & 16 & ASE 33511 \\
\hline & Sesbania virgata (Cav.) Pers & $\mathrm{AM}$ & 1 & ASE 33534 \\
\hline & Crotalaria incana $\mathrm{L}$. & $\mathrm{AM}$ & 2 & ASE 33573 \\
\hline & Vigna adenantha (G. Mey.) Marechal et al. & $\mathrm{AM}$ & 2 & ASE 33525 \\
\hline & Crotalaria pallida Aiton & $\mathrm{AM}$ & 1 & ASE 33528 \\
\hline & Macroptilium lathyroides (L) Urb. & $\mathrm{AM}$ & 3 & ASE 33535 \\
\hline & Vigna sp. & $\mathrm{AM}$ & 2 & ASE 33526 \\
\hline & Senna obtusifolia (L) H.S. Irwin \& Barneby & $\mathrm{AM}$ & 1 & ASE 33552 \\
\hline & Chamaecrista sp. & $\mathrm{AM}$ & 3 & ASE 33527 \\
\hline & Mimosa pigra $\mathrm{L}$ & $\mathrm{AM}$ & 3 & ASE 33532 \\
\hline & Mimosa pudica $\mathrm{L}$. & $\mathrm{AM}$ & 2 & ASE 33549 \\
\hline \multirow[t]{2}{*}{ Hydrocharitaceae } & $\begin{array}{l}\text { Apalanthe granatensis (Humb. \& Bonpl) } \\
\text { Planch }\end{array}$ & SUB ROT & 12 & ASE 33563 \\
\hline & Najas guadalupensis (Spreng.) Magnus & SUB ROT & 2 & ASE 33563 \\
\hline Hydroleaceae & Hydrolea spinosa $\mathrm{L}$. & $\mathrm{AM}$ & 3 & ASE 33531 \\
\hline Juncaceae & Juncus sp. & EM & 5 & ASE 33577 \\
\hline Lamiaceae & Hyptis brevipes Poit. & $\mathrm{AM}$ & 1 & ASE 33551 \\
\hline Malvaceae & Waltheria indica $\mathrm{L}$. & $\mathrm{AM}$ & 1 & ASE 33600 \\
\hline \multirow[t]{4}{*}{ Onagraceae } & Ludwigia helmintorrhiza (Mart.) O. Hara & FFLU & 10 & ASE 33571 \\
\hline & Ludwigia octovalvis (Jacq.) P.H. Raven & $\mathrm{AM}$ & 3 & ASE 28107 \\
\hline & Ludwigia leptocarpa (Nutt.) O. Hara & $\mathrm{AM}$ & 6 & ASE 33537 \\
\hline & Ludwigia nervosa (Poir) & $\mathrm{AM}$ & 1 & ASE 33515 \\
\hline
\end{tabular}


Table 1. Cont.

\begin{tabular}{|c|c|c|c|c|}
\hline Family & Specie & Life Form & Richness & Voucher \\
\hline \multirow[t]{3}{*}{ Passifloraceae } & Piriqueta racemosa (Jacq.) Sweet & $\mathrm{AM}$ & 1 & ASE 33499 \\
\hline & Piriqueta cistoides (L) Griseb & $\mathrm{AM}$ & 2 & ASE 33601 \\
\hline & Turnera subulata $\mathrm{Sm}$ & $\mathrm{AM}$ & 3 & ASE 33500 \\
\hline Plantaginaceae & Stemodia maritima $\mathrm{L}$. & $\mathrm{AM}$ & 3 & ASE 33524 \\
\hline \multirow[t]{9}{*}{ Poaceae } & Paspalum millegrana Schrad & $\mathrm{AM}$ & 3 & ASE 29543 \\
\hline & $\begin{array}{l}\text { Megathyrsus maximus Jacq. B.K. } \\
\text { Simon \& S.W.L. Jacobs }\end{array}$ & $\mathrm{AM}$ & 1 & ASE 33565 \\
\hline & Rugoloa pilosa (Sw.) Zuloaga & $\mathrm{AM}$ & 1 & ASE 33605 \\
\hline & Urochloa decumbens (Stapf) R.D. Webster & $\mathrm{AM}$ & 4 & ASE 33518 \\
\hline & $\begin{array}{l}\text { Hymenachne pernambucensis (Spreng.) } \\
\text { Zuloaga }\end{array}$ & SUB ROT & 8 & ASE 33555 \\
\hline & Urochloa sp. & $\mathrm{AM}$ & 1 & ASE 33602 \\
\hline & Steinchis malaxum (Sw) Zuloaga. & $\mathrm{AM}$ & 1 & ASE 33561 \\
\hline & Pennisetum sp. & $\mathrm{AM}$ & 1 & ASE 33539 \\
\hline & Pennisetum setosum (Sw.)Rich. & $\mathrm{AM}$ & 1 & ASE 33512 \\
\hline Pontederiaceae & Pontederia crassipes (Mart.) Solms & FFLU & 25 & ASE 33495 \\
\hline Potamogetonaceae & Potamogeton pusillus L. & SUB ROT & 1 & ASE 33583 \\
\hline \multirow[t]{2}{*}{ Rubiaceae } & Borreria verticillata $(\mathrm{L}$.$) G. Mey$ & $\mathrm{AM}$ & 1 & ASE 33509 \\
\hline & $\begin{array}{l}\text { Pentodon pentandru s(K. Schum. \&Thonn) } \\
\text { Vatke }\end{array}$ & $\mathrm{AM}$ & 1 & ASE 33564 \\
\hline Salviniaceae & Salvinia auriculata Abl. & FFLU & 20 & ASE 33497 \\
\hline Sphenocleaceae & Phenoclea zeylanica Gartn & $\mathrm{AM}$ & 1 & ASE 33572 \\
\hline \multirow[t]{2}{*}{ Verbenaceae } & Lantana camara $\mathrm{L}$. & $\mathrm{AM}$ & 1 & ASE 33576 \\
\hline & Stachytarpheta angustifolia Mill Vahl & $\mathrm{AM}$ & 2 & ASE 33533 \\
\hline
\end{tabular}

Among the used estimators, Jack1 and Chao 2 present higher number of estimated species than collected species. The bootstrap estimator is the most similar to the actual collection values. The collected species at the Vetiver grass Contour Line site presented values more similar to those of the estimators, while at the Vegetated Riprap site the number of estimated species was higher than the collected, noting that the same pattern was maintained for the other sites. Lolis \& Thomaz (2011) also identified underestimation patterns of species at the sampling sites.

The similarity analysis (ANOSIM) showed significant differences in the composition of macrophytes communities between some of the sampling sites (Tab. 2).

Among the sites where significant differences were detected, the Vegetated Slope and the Cribwall sites, and Vegetated Slope and Vetiver grass contour line sites should be highlighted; however, there was species overlap. Observing the similarity analysis, it was clear that the macrophytes communities in the Vegetated Slope and in the Cribwall are quite similar. This is a characteristic related to nearby areas, which enables the homogeneity of species, due to their dispersing agents. Other studies have also found species overlap among sampling sites. Rodrigues (2017), in Guarapiranga dam, São Paulo, identified different patterns in the composition of macrophytes in different banks. Almeida (2012) also found differences in the macrophytes composition between sampling periods, with species overlap. These factors can be directly related to the river water level, and wind speed, creating problems to the colonization of macrophytes, specially the floating and submerged ones. 


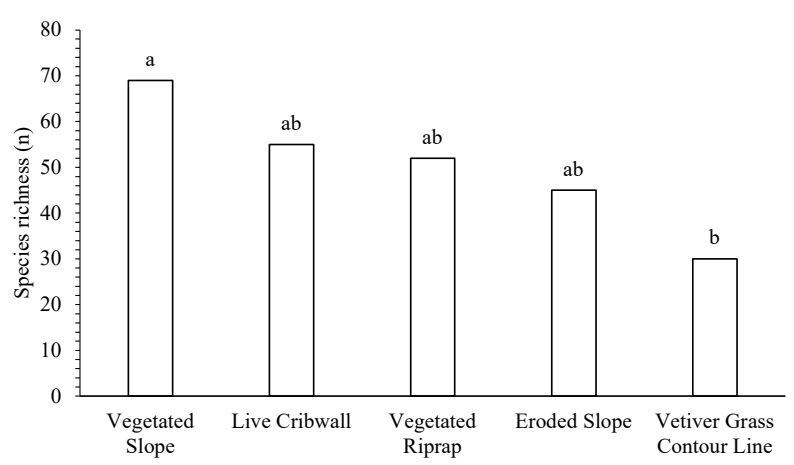

Fig. 2. Species richness of aquatic microphytes sampling sites at Amparo de São Francisco.

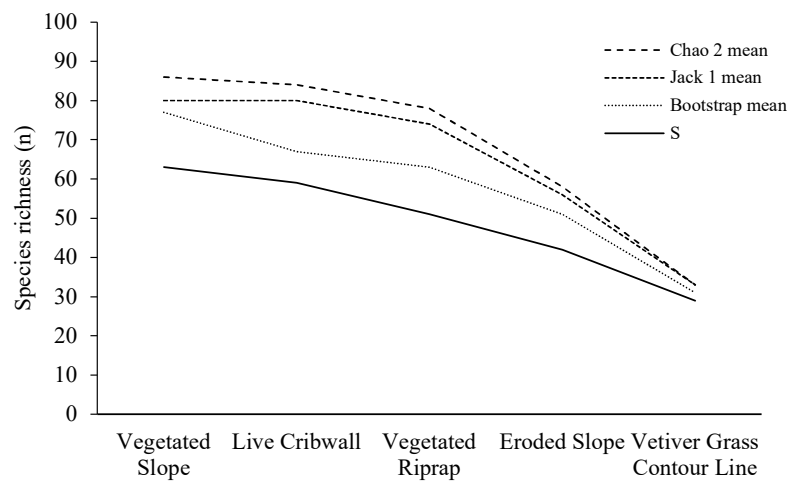

Fig. 3. Observed and estimated species accumulation curve at the sampling sites in municipality of Amparo de São Francisco, Sergipe state, 2014.

Table 2. Similarity analysis (ANOSIM) for macrophytes communities at the sampling sites in the municipality of Amparo de São Francisco, Sergipe state, 2014. sites $\left({ }^{*} \mathrm{p}<0.05\right)$

\begin{tabular}{ccccc}
\hline & Sampling sites & R & P value \\
\hline Vegetated Slope & $\mathrm{X}$ & Vegetated Riprap & 0.2139 & 0.04 \\
Vegetated Slope & $\mathrm{X}$ & Eroded Slope & 0.1907 & 0.07 \\
Vegetated Slope & $\mathrm{X}$ & Cribwall & 0.4907 & $0.001^{*}$ \\
Vegetated Slope & $\mathrm{X}$ & Vetiver grass Contour Line & 0.3056 & $0.02^{*}$ \\
Vegetated Riprap & $\mathrm{X}$ & Eroded Slope & 0.1185 & 0.18 \\
Vegetated Riprap & $\mathrm{X}$ & Cribwall & 0.1972 & 0.05 \\
Vegetated Riprap & $\mathrm{X}$ & Vetiver grass Contour Line & 0.1204 & 0.10 \\
Eroded Slope & $\mathrm{X}$ & Cribwall & 0.2056 & 0.06 \\
Eroded Slope & $\mathrm{X}$ & Vetiver grass Contour Line & -0.075 & 0.77 \\
Cribwall & $\mathrm{X}$ & Vetiver grass Contour Line & 0.2343 & 0.02
\end{tabular}

\section{CONCLUSIONS}

Asteraceae, Fabaceae, Poaceae families were predominant in the community of aquatic macrophytes and Amphibious was the predominant life form.

The Vegetated Slope site presented the greatest richness of species among the sampling sites, confirming the importance of slope protection, an attractive environment to other species.

In the species accumulation curve, the estimated value was higher than the collected value, and the boostrap values are closer to the actual values of the collection.

The species diversity confirms the importance of this community in ecological succession.

\section{ACKNOWLEDGMENTS}

The authors thank the Conselho Nacional de Desenvolvimento Científico e Tecnológico (CNPq), for financial support.

\section{REFERENCES}

Almeida, G.W.2012.Aspectos ecológicos da comunidade de macrófitas aquáticas na Represa do Funil, MG: Perspectiva para o manejo. Tese 154f., Universidade Federal de Larvas, Minas Gerais.

Andrade, K. V. S. D., Holanda, F. S. R., Santos, T. D. O., Santana, M. B. S. \& Araújo Filho, R. N. 2018. Mangrove Soil in Physiographic Zones in the São Francisco river estuary. Floresta e Ambiente 25(2):1-9.

Araújo, E.S., Sabino, J.H.F., Cotarelli, V.M., Filho, J.A.S. \& Campelo, M.J.A. 2012.Riqueza e diversidade de macrófitas aquáticas em mananciais da Caatinga.Diálogos \& Ciência32 (1):229-233.

Araujo-Filho, R.N., Holanda, F.S.R. \& Andrade, K.R. 2013. Implantação de técnicas de bioengenharia de solos no controle da erosão no baixo São Francisco, estado de Sergipe. Scientia Plena 9 (7):1-9.

Araújo-Filho, R. N., Holanda, F. S. R., Pedrotti, A., Oliveira Santos, T., \& Rocha, I. P. (2017). Influência dos atributos físicos-mecânicos do solo na estabilidade do talude do baixo São Francisco. Scientia Agrária, 18(4), 107-113.

Bianchini Junior, I., Cunha-Santino, M.B., Fushita, A.T., Almeida, D.A.A. \& Maia, A.T. 2010. Monitoramento das Macrófitas Aquáticas do Reservatório da Usina Hidrelétrica Luís Eduardo Magalhães (Estado de Tocantins, Brasil). Augmdomus 2 (1): 38-48.

Bini, L.M., Thomaz, S.M. \& Souza, D.C. 2001. Species richness and beta-diversity of aquatic macrophytes in the Upper Parana River floodplain. Archiv fur Hydrobiologie151(1): 511-525. 
Chazdon, R.L., Colwell, R.K., Denslow, J.S. \& Guariguata, M.R. 1998. Statistical methods for estimating species richness of woody regeneration in primary and secondary rain forest on Northeastern Costa Rica. In: Dallmeier, F. \& Comiskey, J.A. (eds.) Forest biodiversity research, monitoring and modeling. Parthenon Publishing Group, Washington. p.285-309.

Chen, S. \& Wang, D. 2019. Responses of decomposition rate and nutrient release of floating-leaved and submerged aquatic macrophytes to vertical locations in an urban lake (Nanhu Lake, China). Chemistry and Ecology 35(5):431-444.

Colwell, R.K. 1997. Estimate S 9.1: Statistical Estimation of Species Richness and Shared Species from Samples. Disponível em: http:// viceroy.eeb.uconn.edu/EstimateS/. Acesso em: 30.12.2015.

Costa, E. C., Holanda, F. S. R., Sussuchi, E. M., Bomfim, L. S. \& de Araújo Filho, R. N. (2020). Potencial alopático do Chrysopogon zizanioides e Paspalum millegrana na germinação de alface. Iheringia. Série Botânica 75:1-7.

Cullen, J.R.L., Rudran, R. \& Valladares-Padua, C. 2006. Métodos de estudos em biologia da conservação e manejo da vida silvestre in Larry Cullen Jr., Claudio Valladares-Padua, Rudy Rudran (organizadores); Adalberto Jose dos Santos... [et al.J: - 2. ed. rev. - Curitiba: Ed. Universidade Federal do Paraná, 652p.

Dhir, B. 2015.Status of Aquatic Macrophytes in Changing Climate: A Perspective. Journal of Environmental Science and Technology 84 (1):139-148.

Ferreira, D.F. 2011.Sisvar: a computer statistical analysis system. Ciência e Agrotecnologia Lavras, 35(1): 1039-1042.

García-Girón, J., Fernández-Aláez, M., \& Fernández-Aláez, C. 2019. Redundant or complementary? Evaluation of different metrics as surrogates of macrophyte biodiversity patterns in Mediterranean ponds. Ecological indicators 101: 614-622.

Howard, R. J., Biagas, J. \& Allain, L. (2016). Growth of common brackish marsh macrophytes under altered hydrologic and salinity regimes. Wetlands 36(1): 11-20.

Holanda, F. S. R., Santos, C. M., Casado, A. P. B., Bandeira, A. A., Oliveira, V. S., Fontes, L. C. S., Rocha, I. R., Araújo-Filho, R. N., Góis, S. S. (2007). Análise multitemporal e caracterização dos processos erosivos no Baixo São Francisco sergipano. Revista Brasileira de Geomorfologia (8):87 - 96.

Holanda, F. S. R., Bandeira, A. A., Rocha, I. P., Araújo-Filho, R. N., Ribeiro, L. F., Ennes, M. A. (2009). Controle da erosão em margens de cursos d'água: das soluções empíricas à técnica da bioengenharia de solos. Editora UFPR - R. RA'E GA Curitiba, (17): 93 - 101.

INMET - Instituto Nacional De Meteorologia. Disponível em: http:// www.inmet.gov.br/portal/index.php? $\mathrm{r}=\mathrm{bdmep} / \mathrm{bdmep}$. Access em 30.08.2015.

Lolis, SF \& Thomaz, SM 2011. Monitoramento da composição específica da comunidade de macrófitas aquáticas no reservatório Luis Eduardo Magalhães. Planta daninha 29 (2): 247-258.
Lorenzi, H. 2008. Plantas daninhas do Brasil: terrestres, aquáticas, parasitas e toxicas in Harri Lorenzi. - 4. Ed. - Nova Odessa, SP: Instituto Plantarum, 640p.

Machado, L., Holanda, F. S. R., Pedrotti, A., Ferreira, O. J. M., Araújo Filho, R. N. D. \& Moura, M. M. 2018. Effect of vetiver roots on soil resistance to penetration in a typic Fluvic Neossol in the São Francisco riverbank. Revista Caatinga 31(4):935-943.

Mormul, P.R., Ferreira, F.A., Michelan, T.S., Carvalho, P., Silveira, M.J. \&Thomaz, S.M.2010.Aquatic macrophytes in the large, subtropical Itaipu Reservoir, Brazil. Revista de Biologia Tropical 58 (1):1437-1452.

Moura, R. S. T. \& Henry-Silva, G. G. 2018. Is there a zonation pattern in aquatic macrophytes communities in the aquatic environments of the Brazilian semiarid? Brazilian Journal of Botany 41(3):665-674.

Moura Júnior, E. G. D. \& Cotarelli, V. M. 2019. An update on the knowledge of aquatic macrophytes in Northeast Brazil. Rodriguésia 70:1-11.

Oliveira, T.S, Santana, K. V. A., Santos, H. V. S., Araújo Filho, R. N. \& Holanda, F. S. R. (2019). Floristic and structural characterization of the mangrove forests in the estuary of the São Francisco river. Floresta 49(2):163-170.

Rocha, I. P., Holanda, F. S. R., Rolim, M. M., Lino, J. B. \& de Araújo Filho, R. N. 2018. Magnitude and spatio temporal variation of the erosion on the slope of the lower São Francisco River, Northeastern Brazil. Journal of Experimental Agriculture International 1:1-11.

Rodrigues, M. E. F., Souza, V. C., \& Pompêo, M. L. M. 2017. Levantamento florístico de plantas aquáticas e palustres na represa Guarapiranga, São Paulo, Brasil. Boletim de Botânica, 35, 1-64.

Peel, M.C., Finlayson, B.L. \& Mcmahon, T.A. 2007. Updated world map of the Koppen-Geiger climate classification. Hydrology Earth System Science 11 (1) 1633-1644.

Pott, V.J., Pott, A. 2000. Plantas aquáticas do Pantanal. Brasília: Embrapa, $404 \mathrm{p}$.

Shah, M., Hashmi, H.N., Ghumman, A.R. \& Zeeshan, M. 2015. Performance assessment of aquatic macrophytes for treatment of municipal waste water. Journal of the South African Institution of Civil Engineering 57(1):18-25.

Souza, V.C. \& Lorenzi, H. 2008. Botânica Sistemática: guia ilustrado para identificação das famílias de fanerógamas nativas e exóticas do Brasil, baseado em APG II in Vinicius Castro Souza / Harri Lorenzi. -2 Ed. Nova Odessa, SP: Instituto Plantarum, 640p.

Sponchiado, M., \& Schwarzbold, A. 2009. Control of the aquatic macrophyte Luziola peruviana Juss. ex Gmel by grass carp (Ctenopharyngodon idella Valenciennes, 1844) grazing. Acta Limnologica Brasileira 21(2):193-197.

Stokes, A., Sotir, R., Chen, W., Ghestem, M. 2010. Soil bio- and ecoengineering in China: past experience and future priorities. Ecological Engineering 36:247-257.

Westake, D.F. 1974. Macrophytes. Pp. 32-41. In: WOLLENWEIDER, R.A. (ed.). A manual for measuring primary production in aquatic environments. Oxford, Blackwell Scientific. 